\title{
The Politics of Development Economics and Peacebuilding: A Postcolonial Global North Hegemonic Agenda?
}

\author{
Oluwagbemiga Dasylva \\ George Mason University
}

Development economics or international development aid emerged to channel economic resources from the Global North to the developing world for development purposes. Critics have drawn attention to how development economics or international development aid and the more recent approaches to peacebuilding have become conservative if not neo-colonial enterprises. The imperialist/colonies' interaction had existed before and served as harbingers of, the donor/recipient interaction. There is still great suspicion among critics that there has not been any significant departure from this historic past and "colonial" mindset, and what characterize today's economic aid transactional dynamics. Through secondary data analysis and archival studies, the paper explains the classic narratives of internationalization of development economic aid, the original design, and objectives, the praxis, benefits or outcomes for the Global North, and the implications for the developing world (Global South). The methodology engages the various critical approaches to international development and where these neo-colonial sentiments may have originated from as well as the informing rationale.

Keywords: international development aid, development economics, peacebuilding, colonialism, neocolonialism

\section{INTRODUCTION}

Some of the critical opinions on development economics or international development aid suggest the intention to increase the West's involvement in Africa. Development economics or international development aid constitute the 'anti-thesis' of, and a veritable "damage control" to, the colonial psychosocial and economic experience of the colonized. The consequences of imperialism in postcolonial spaces cast a shadow on postcolonial interventions exerted through foreign aids. Scholars, including Harry Magdoff, David Birmingham, and Ebenezer Obadare (2010), argue that Africa "being former colonies, continue in different ways to display the imprints of European colonialism." They suggest that there are residues of colonial mind-set in former colonies, one of which is the dependence that international development aid or development economics amplifies. Development economics or international development aid and the free market are two contrasting and reinforcing ideas. As Heathershaw and Lambach (2019) explain, "international actors make intrusive interventions into sovereign space of a given state” (pp. 269-290). By 'Intrusive', it connotes action taken without consent.

Thus, under colonialism intervention(s) were made without sufficiently considering the culture of recipients' sovereignty. In comparison, Newman and Richmond (2009) opine that "peacebuilding activities are not neutral in their normative orientation or impact" (p.9). Their idea suggests that interventions are not 
altruistic, bearing in mind that within the confines of the free market, the Haute finance is largely about 'interest' more than anything else. For instance, Joseph Stiglitz (2006), opines, "I was convinced that the advanced industrial countries, through international organizations like the International Monetary Fund (IMF) .... and the World Bank, were not only not doing all they could to help these countries but were making life more difficult" (p. ix). Likewise, Sahin Kirdin (2017) argues, "since there is no formally recognized supreme authority among equally sovereign units, states generally act in 'self-help' to maximize their national interest" (pp. 615-632). It is not far-fetched to conclude that economic development as an approach to international development is a tool that perpetuates the interests of interveners. Existing relevant literature on post-independent Africa has demonstrated that there is always interest in interventions.

The terms, "development", "global north" and "global south", as used broadly in this context, define economic indicators. They characterize, on the one hand, developed and rich system economy, and on the other hand, underdeveloped and poor system economy. The emphasis is not on 'economy' but the foregrounding 'systems.' Systems are influenced by certain ideological orientations that run through the socio-economic and political landscape of the two worlds. Therefore, the intersectionality of the developing economy and colonialism is what we see between the Global North and Global South. Dimiter Toshkov's critique of the designation as misleading, and at best, "descriptively inaccurate, even when they refer to general notions such as (economic) development" (Toshkov, 2018) is apt, and further underscores the significance in this context. Toshkov contends that they are, "homogenizing, obscuring important differences between countries that are supposedly part of the Global South and North Groups." Despite the overlapping ramifications of their use, Lemuel Odeh (2010) asserts, "while the Global North represents the economically developed societies of Europe, North America, among others, the Global South represents the economically backward countries of Africa among others." Odeh's classification resonates with the intentions of this paper for clarity.

The imperialist/colonies interaction had existed before and served as harbingers of, the donor/recipient interaction that characterizes today's transactional dynamics. The colonial policy and the territorial cumeconomic expansionist mindset foregrounded by Europe's feudalist-capitalist ideology were designed to aid Europe's industrial revolution. Through colonialism, Africa presented an opportunity to advance Europe's economic interests consequent upon the partitioning of Africa at the historic Berlin conference of 1884-85. Meanwhile, precolonial African space had had its state formations and conducted businesses in line with, and peculiar to, the dynamics of its cultural space and traditions. As Thea Buttner (1970) explains, "In the precolonial period, many peoples in Tropical Africa attained a relatively high standard of development which by every measure compared favorably with that of the other people" (p. 275). The critic cites ancient Ghana, Mali, and especially, the City-States of Benin and Ile-Ife (now, in Nigeria), as representatives of this idea of developed African societies. Nevertheless, imperialists dominated Africa through its established institutions which deliberately obliterated existing African institutions through enforced, direct, or indirect assimilation. Gareth Austin (2008), Walter Rodney (1972), wrote extensively on the pressure that the burgeoning industrialized world had on Africa.

The dislocation of a thriving pre-colonial Africa was well-orchestrated for reasons of the proper administration of Europe's imperial policies. The consequences were immense, including loss of originality of ideation, warped perception of reality, and incapacitated mental processing of challenges and innovations. It results in total dependency of Africa on foreign aid, in particular, the post-independence Africa (p.15). Rodney argues that the system and processes that could have aided Africa's development in the age of globalization were truncated by hangovers of colonial legacies, and persistent foreign interference in postcolonial Africa. Notwithstanding the misinformed vilification of Africa's pre-colonial development as backward by colonialist Europe, Africa's loss of manpower was at the heart of its colonial interaction with Europe. Rodney attributes the slow development that Africa grapples within the 21st century as a direct consequence of the labor loss. Rodney (1972) criticizes Europe's "civilizing mission" (p.322), categorizing it as a narrative that had an overwhelming influence of racism. The reality of Europe's "civilizing mission" is the "loss of development opportunity ...the lines of economic activity attached to foreign trade were either destructive, as slavery was, or at best purely extractive" (p. 105). Daron Acemoglu, 
Simon Johnson, and James Robinson also reference the imperialists' strategic execution of models that stunted Africa's 'development'. Similarly, Matthew Lange, James Mahoney \& Matthias vom Hau (2006) suggest, "colonialism reversed levels of development in much of the non-European world" (pp. 1412-1462). Lange, et al., concludes that "the economic models of the colonizing nations affected the reversals of fortune in these spaces" (p. 1412). At the core of the criticism against development economics or international development aid, is the consistent furthering of the Westphalian hegemony. It can be extrapolated within the confines of colonial imperialism which has always been the relationship between the two global economies as a neo-colonial enterprise.

\section{DEVELOPMENT AID, INTENTION(S): A RATIONALE FOR COUNTER-DISCOURSE}

Foreign aid is one of the approaches to international development. The flurry of conflicts in the Global South is one of its significant markers. Thus, Africa's conflicts have been the rallying point for the West's renewed post-independence interventions. Thus, the various approaches to international development, including peacekeeping, peacebuilding, and development initiatives have since been West's alibi for occupying underdeveloped or developing spaces. Christiana Sherman (n.d) critiques this apparent continuum stating, "despite this level of donor contribution and the trillions of dollars that have come before it, billions of people still live on less than two dollars a day, millions don't have access to clean water and millions of children still aren't able to go to school." While it is the common narrative to position international development as tackling poverty, conflicts, and improving education and addressing the issue of inalienable human rights, the system seems to be failing. But these are all traceable to, and consequences of, colonial activities and the culture of the international aid organizations which translates as the culture of dependency. The amalgamation of independent and incompatible societies is also germane to protracted conflicts in many former colonies. Nigeria, Sudan, Ethiopia, Eritrea, and so on, experience crises due to the colonial fusion of unlikely nationalities within a geographically defined space. The amalgamation, primarily for ease of colonial administration, and the prospects of democracy have increased the tendency for ethnic-based policies and governance, as well as a basis for demands and agitations. There is the preponderance of the usually favored ethnic majority that is detrimental to their minority counterparts.

Paul Zeleza (2000) opines, "There is hardly any zone of conflict in contemporary Africa that cannot trace its sordid violence to colonial history and even late nineteenth century." One can deduce from the submissions of Acemoglu, et al., that the differences in the way colonizers governed their territories, also form the basis for the consequences on how colonies transit into independence and post-independence (p.1373). Francophone and Anglophone West African countries exemplify this, as Alain Faujas (2012) opines, "French-speaking Sub- Saharan Africa is lagging behind English-speaking African... countries belonging to the mainly French-speaking Economic Monetary Union of West Africa have been growing at an average rate of 3.4 percent per annum... while those of the mainly English-speaking East African community have registered a 5.4 percent growth rate." Current trends are suggestive of the diverse colonial orientations. In Daron Acemoglu and James Robinson's (2012) Why Nations Fail: The Origins of Power, Prosperity, and Poverty, the economy and political institutions are pivotal to development. Former funded Europe's industrial revolution, the latter legitimizes imperial policies. It is these two areas that the approaches to international development attempt to address but the historical narrative flaws the rationale of foreign interveners.

There is a growing contention between critics and those who contend that development economics or international development aid is intended for the good of the Global South. Critics have argued that development, as understood by either side, ought to be within the confines of a given experience and culture. In other words, "development" is as perceived by a worldview, but it has been the Western culture influencing preferred or selected images that it projects on the Global South. Likewise, the Global South's culture influences its perception of the interventions from the Global North. Thus, the conception of development in the Global South differs from how it is conceived in the Global North. James Ferguson in

The Anti-Politics Machine argues in favor of defining 'development' concerning post-conflict spaces. He insists that it allows for a proper (re)evaluation of what 'development' is, or is not, within that space (p. 
xiv). Andre Gunder Frank (1969) expressed similar sentiment stating, "the people of Africa, Asia, and Latin America have not always defined their contexts as "developed' or not" (p.73). And yet, interventions, despite abounding contentions are constantly initiated with interveners' 'theories of change'. This is not only indicative of gaps between interveners and recipients but the power dynamics evident in the relationship. Iraq, Afghanistan, Libya, and Mali, among others, continue to demonstrate this.

Pamina Firchow (2018) argues, "Current international peacebuilding efforts are not very effective at achieving peace by local standards because attention is paid to reconstruction, governance, and development assistance with little attention paid to community ties and healing." (p.28). She gives insight into the intersectionality of development and peacebuilding, on the one hand, and criticizes the models of engaging peacebuilding and development in underdeveloped or post-conflict spaces by foreign interveners. Firchow suggests a methodology that draws indicators of peace, conflict resolution, and development from the 'local' population (p. 110). Perhaps, it should be emphasized that western-centric perception of development can only respond adequately to, or proffer necessary solution to, western-centric problems, but might prove grossly inadequate for non-western challenges, given the peculiarities. The realities that call for Firchow's everyday peace indicator are the failed interventions based on rather presumptuous 'theories of change' for underdeveloped countries' constantly trying to project the image of what they are not. Lederach de-emphasizes the function of power and authority as emphasized by Virginia Fortna. For Fortna, effective peacebuilding and development interventions are absolutes and a function of power. In today's international development the prevalent power asymmetry has not yielded expected outcomes. Susan Woodward (2007) stresses, "the cause of the failure or less than adequate outcomes is the failure to address the "root causes' of conflict" (pp. 143-170). Woodward's idea underscores the view that the apparent failure of international development is traceable to its deliberate disregard for the effects of colonialism in the various former colonies.

From the foregoing, the various approaches to international development and peacebuilding underscore the importance and the presence of conflict. The approaches provide post-conflict solutions, and it was only after the Cold War that peacebuilding and international development rose to prominence. This is not to say that Africa was at the center of the Cold War, but the continent was and still is a pawn. Development and peacebuilding in the Global South are largely post-colonial phenomena, though post-World War II Europe had this form of intervention with America's Marshall Plan. Institutions like the International Monetary Fund and the World Bank, United Nations Conference on Trade and Development were tools intended for post-World War II development but are now being used for international development in the Global South and guided by their culture. For instance, Stiglitz states "the head of the World Bank, charged with promoting development, has always been appointed by the President of the United States (without even consulting his Congress). American politics, not qualifications, are what matters." Hence, peacebuilding is recognized as "an activity that has come to involve a major role for development and development actors." (Berdal, 2014, 362-378).

Irene Bono and Beatrice Hibou (2017) explore the multidimensionality of development and conflict. They describe development as, "a complex social relationship, involving a vast constellation of actors, interests, logics, spaces, causalities, and temporalities" (pp.3-36). Hence, while it can be argued that the colonial era legitimizes imperialism that developed Europe, the Cold War, on the other hand, legitimizes the Eastern and Western power blocs' plundering of the already broken systems in Africa. Independent African countries was a response to the brewing cold war between the major ideological blocs. Jesse Heitz (2016) states, "in the interest of avoiding a full break-in Anglo-African relations and the possible infusion of communist influence into African struggles, the British fast-tracked their withdrawal from Africa, starting on the Gold Coast in 1957" (pp. 427-430). Benjamin Talton quotes then British Prime Minister Harold Macmillan's Wind of change (1960) "the growth of national consciousness in Africa is a political fact and we must accept it...if we cannot do so we may peril the precarious balance between the East and West on which the peace of the world depends." His idea undercut the West's interest in Africa, one which was done by offering development aids.

Richard Miller (2000) opines, "the ethics of humanitarian intervention cannot be readily subsumed by the ethics of just war without due attention to matters of political and moral motivation" (pp. 3-35). While 
Miller draws on the ethics of humanitarian intervention, Solon Simmons analyses the dynamics from the angle of a narrative. The idea of interventions as opined by Miller and Heitz are similar, but from different perspectives, hence, drawing on the notion of subjectivity. Simmons (2019) explains subjectivity as a narrative that thrives on the abuse of power. He identifies "four paradigmatic representations of the abuse of a kind of institutional power ...." (p. 5). Within the purview of power, is the question of influence on interventions, and perceptions of recipients. What influenced colonialism is a function of one of the four narrative imaginations discussed by Simmons. Basis of the methodology erects narratives some of which question the West's altruism as projected by their various interventions. For instance, the tenet of the International Monetary Fund (IMF) in Ghana, Nigeria, and other developing countries is a case in point. The Structural Adjustment Program (SAP) of the IMF saw the economic downturn of countries that bought into it. Stiglitz (2006), for instance, states that "countries seeking foreign aid were specifically asked to meet a large number of conditions; ... the enormous number of conditions often distract governments from more vital tasks" (p.14).

Francis Ogbimi (1998) explains that this was because the liberal peace model represented by the haute finance "is incompatible with the structure of developing economies" (pp. 23-30). It ties to Stiglitz's opinion on the World Bank and the International Monetary Fund. According to him, "many developing countries face a huge burden of debt. In some, half of some or more of their government spending has to be used to service debt, taking away money that could be used for schools, roads. Development is difficult as it is; with the debt burden, it becomes virtually impossible" (p. 15). That case resonates with the realities of the liberal peace model of governance--democracy. If precolonial African societies were portrayed in literature as underdeveloped in the Westphalian attribution of development, such descriptions, validate any form of intervention that the Western narrators think is appropriate to alleviate Africa from its underdevelopment. Basil Davidson (1995) contends, "African history and development had been measured by the European concept of development" (p. 57). In other words, "development," is what Europe projects on Africa, through its lens. Davidson describes pre-colonial economic activities in Africa as vibrant. The foregoing is indicative of the rather curious narratives that revolve around the issue of development in Africa and how interventions, however subjective. Through the lens of interveners, they are appropriate because it ties to the master narrative of Africa's gross underdevelopment. These narratives of an underdeveloped Africa induce the various approaches to development economics or international development aid like peacekeeping, peacebuilding, and development initiatives earlier mentioned.

\section{APPROACHES TO INTERNATIONAL DEVELOPMENT: THE NEO-COLONIALIST TWIST}

There are various approaches to international development some of which will be mentioned here. However, these approaches have over the years evoked strategic responses. There is the idea that interventions in today's globalized economy are an extension of how the Global North engaged the Global South in the colonial period. For instance, Keri Phillips' (2013) assertion that international development aid began with European colonialism is apposite here. According to him, "foreign aid structures that began with European colonialism have become tied to shifting economic and political interests, as well as a growing humanitarianism movement." What previous colonies are benefitting from today like the rail, roads, and ports were initially meant to facilitate the movement of raw materials like farm produce, cocoa, palm oil, groundnut, coffee, and so on, from the interior. In other words, it was primarily to further the exploitation of the colonies. Even when research grants were given, they were skewed in favor of the social sciences, not in core sciences or medicine. The granting agencies, like Ford and Rockefeller Foundations, determined and decided the direction of the research interests, usually, data gathering on physical and human geography (local demography, cultural temperament, and general sociology of the people, including their occupations, forms, and content of trade and commerce, location of natural mineral deposits, etc.). All of these are suggestive of tracking and mapping possible areas that were good for the exploitation and prospecting of natural resources.

Therefore, the argument is that provision of aid in colonial time was a means to an end, furthering the exploitation of both natural and human resources of the colonies. The goal of development economics or 
international development aid, as an intervention model, is peculiar against the ironies brought to the fore by Ehiedu Iweribor. He describes development aid as one "characterized by European institutions that were designed to develop African economies as primary-product exporters." The intentions of colonialism stem from the economic, political, and social factors that were at play at the time. By the foregoing, development interventions are tools of the West to maintain hegemonic influence on recipients. The irony becomes more obvious in Patrick Manning's (1998) expression of the colonial experience, in which "the government continued to receive more in tax from Africa than it spent in Africa" (p.123). Douglas Rimmer (1992) also notes that African farmers were forced to save "in British government bonds, and this assisted the British metropolitan economy to recover from the post-war dollar shortage" (pp.41-42). The above description would seem like development economics or international development aid in reverse because it undercuts the idea of what development economics or international development aid espouses today.

There is a consensus of models for engaging international development that ties to globalization. However, the consequences of globalized inequalities have always created controversies on what the initiative gives the most effective results. For instance, the culture of the International Monetary Fund (IMF) and its conditionality for a bailout, has been described as one that often puts the economy of recipient developing countries at risk. Stiglitz states, "The world's developing countries owe roughly $\$ 1.5$ trillion to creditors including the World Bank and the IMF and despite debt forgiveness, the level of indebtedness by low-income countries continued to increase" (p.15). Scholars in support of the positive attributes of globalization suggest that globalization processes have reduced global inequalities, for example, Malaysia, and China, to mention a few. Stiglitz rather argues, "the history of development economics is marked by the proverbial 'Don- Quixotic' quest to find 'the answer,' disappointment in the failure of one strategy leading to the hope that the next will work" (p. 26). Some contrast the notion, arguing that globalization invokes modernization that sets underdeveloped countries back. For instance, Chuck Thiessen \& Sean Byrne (2018) reference Afghanistan's economic aid, stating, "international intervention in Afghanistan has served a powerful elite in Kabul who have economically benefitted from the injection of foreign resources" (p.4).

Globalization can be described as an extension of the late 19th-century industrial revolution, hence (Richard Baldwin, n.d) opines, "globalization leaped forward in the late 19th century when steam power slashed the cost of moving goods internationally." Baldwin states, "old globalization was especially beneficial to today's rich nations. Britain was the first industrializer maintaining a significant lead until 1900." So, while the paradigm has shifted, and the taxonomy has changed, the informing objectives, functions, and processes associated with the industrial revolution have not. Hence critics of globalization faulted its continuing salience and the consequences associated with it. Bonaventura de Sousa Santo (2019) says this of globalization, "far from being consensual, is a vast and intense area of conflict for various social groups, state, hegemonic interests on the one hand, and social groups, states and subordinate interests on the other hand and, even within the hegemonic camp, there are greater or lesser divisions of this" (p.118).

Therefore, international development and its models are a variety, or aspects, of globalization. The critical school of theorists contends that "development aid as part of neoliberal development agenda, opens up poor countries in developing world to economic exploitation by industrialized nation." On the contrary, the pro-development theorists argue that globalization advances colonial traditions, and it is on this assumption that neo-colonialism finds its root (p.78). Roger MacGinty, Andrew Williams, and Peter Uvin contend the propensity of development aid to induce violent conflict in developing countries. Mary Anderson explains the practice that can create a deliberate balance between the evils and goods of development intervention. According to her, 'to do no harm' is to constantly seek the balance between aid and conflict. She opines that while interveners seek to be neutral and impartial, the impact of an intervention is not neutral about whether it escalates or de-escalates conflict. The images or notion that the idea of development suggests is indicative of the 'Othering' between the Global South and the Global North. The 'Othering' as exemplified by the term has made one view or the other in its respective image, (Odeh, 2010). Thus, neo-colonialism through Othering defines and determines the ways that concepts like "development" and "peacebuilding" have been fabricated and deployed. It creates a system of dependency and promotes false hope of utilitarianism. So, while it may seem that "development" is used in a semiotic or 
conversational sense, the ascription of the term is, on the one hand, consequential to the constant positioning of developing economies and, on the other hand, engenders the age- long subjugation of the Global South to the whims of the Global North.

As used in the field of International Relations, development legitimizes post- colonial phase of the transactional relationship that exists between the two worlds. One that benefits immensely from the status quo at the detriment of the 'Other'. This perpetuates the persistent grip that former colonial 'masters' have on developing economies and the absolute dependence of the latter on the former for interventions through financial aid. Ferguson (1994) explores the solution to this in detail. Independence is clothed in neocolonialism characterized by heavy reliance on aid and other forms of interventions; this undermines and compromises the rather quasi sovereignty. William Brown (2013) controverts this position, arguing that "sovereignty as a right to rule constitutes the very basis of the aid relationship, and endows African states with the agency with which to contest the terms of aid deals" (p. 282). He presents a differing reading of the politics of aid, unlike Christopher Kilby (1999) whose justification of aid is based on its humanitarian merits by striving to do good and consciously do less harm (pp. 79-92). Clemens Six explains that "The idea of development is a product of a long-term relationship between Europe and non-European parts of the world that has for centuries been determined by colonial power relations."

\section{WESTERN HEGEMONY, PEACEBUILDING, AND INTERNATIONAL DEVELOPMENT AID}

William Zartman (1976) stresses the ever-present political and economic influence that Europe exerts on the African continent. From the military proliferation of Europe to a high level of aid and investments, trade and constant flow of human capital from the developed to the underdeveloped countries of Africa, are classic examples of neo-imperialism in the continent. He notes, "the attainment of political sovereignty masks the reality of continued dependence on world economic structures, and calculations of power and interest within dependency relationship explain underdevelopment." That is, in the context of the Eurocentric use of the term "development", Africa, regardless of its sovereignty, is yet to come of age. It is within this relationship of dependency that building peace is explained. The notion of development and underdevelopment is a functional construct that does not necessarily speak to the realities at play in underdeveloped spaces. Rather, a system that legitimizes continued the relationship between assumed politically sovereign nation and its developed counterpart. To further explain this, Zartman asserts that "dependence analysts locate the source of the new nations' developmental problems not in these nations' incapacities but the constraints of international politics and economics." Accepting foreign aids can be tantamount to ceding sovereignty. The statement is illustrative of the construct and overarching designs that perpetually constrain postcolonial spaces, manifesting in subtle indoctrination of African elites to think 'Western.' By so doing, they are cut off from the realities of their own spaces and, therefore, are made to depend on the West for as long as their psyche remains warped and clouded.

\section{CONCLUSION}

The realities of the post-Cold War have seen the intersectionality of peacebuilding and development, thus, becoming tools that have continued to draw Africa's attention to the West. The donor/recipient dynamic is relevant and favorable to the West's maintaining its hegemony, either through its system of government, (democracy) or economic emancipation that ironically poses a challenge to developing spaces (free market). In the same vein, the complexities suggest that the question of the relevance of development economics or international development aid to recipient-nations cannot be resolved in isolation. It has been established that it was part of Europe's policy to create colonial empires to aid expansions, create avenues for trade, and reap the dividends at little or no cost to the imperialist. The nuance of that master-servant narrative still holds because developing countries are yet to transcend that space. It is revealed in this study that economic development or international development aid is consciously skewed in favor of imperialism, to the detriment of the unsuspecting, and often emasculated, recipient-colonies. The study also reveals that international development aid is, among other things, a schemed agenda that is meant to serve, in a rather 
subtle way, as an imperialist tool to perpetuate and sustain the unbridled exploitation of the colonies. Other findings include, specifically, the fact that it is unarguably beneficial, primarily, to the lending nations. This is also considered legitimate in the former colonies where colonial structures were in place.

To establish the linkages between peacebuilding and development economics or international development aid, the paper recommends that interventions must be tackled in a manner of a multi-layered praxis to draw nuanced suppositions. Interventions like peacekeeping, peacebuilding, economic empowerment, to mention a few, are not new strategies to the Global North. However, the manifestation of interventions in post-colonial dispensation should be made to serve the same purpose that the Global North has over the years claimed it was meant to serve. Having taken on its own life, post-colonialism, neocolonialism, and its consequences cannot be overemphasized in the realities of generations that were handed the history of the colonial experience. Conceding that economic development or international development aid are complex processes, the research has brought to the fore its colonial root as the classic form of intervention and development economics or international development aid as the continuation of the classic narrative of the Global North hegemony.

\section{REFERENCES}

Anderson, M. (1999). Do No Harm: How Aid Can Support Peace- or War. Boulder London: Lynne Rienner Publishers.

Argument, A. (2015, June 30). The rise and paradoxes of Pan-Africanism today. Retrieved December 30, 2019, from https://africanarguments. org/2015/06/30/the-rise-and-paradoxes-of-pan-africanismtoday/

Austin, G. (2008). Resources, Techniques, and Strategies South of the Sahara: Revising the factor Endowments Perspective on African Economic Development, 1500-2000. Economic History Review, 61(3), 578-624.

Austin, G. (2010). African Economic Development and Colonial Legacies. International Development Policy, (1), 11-31.

Baldwin, R. (2019, January 21). Globalization 1.0 and 2.0 helped G7. Globalization 3.0 helped India and China instead. What will Globalization 4.0 do? Retrieved December 20, 2019, from https://voxeu.org/content/globalisation-10-and-20-helped-g7-globalisation-30-helped-india-andchina- instead-what-will-globalisation-40-do?

Berdal, M. (2014). Peacebuilding and Development. In R.K. Bruce Currie-Alder, International Development: Ideas, Experience, and Prospects (pp. 362-378). Oxford: United Kingdom: Oxford University Press.

Boatca, M. (2015). Global Inequalities Beyond Occidentalism. Burlington VT: Ashgate Publishing.

Bono, I., \& Hibou, B. (2017). Development as Battlefield. Boston: Graduate Institute Publications, BrillNijhoff.

Brown, W. (2013). Sovereignty Matters: Africa, Donors, and the Aid Relationship. African Affairs, 112(447), 262-282.

Buttner, T. (1970). The Economic and Social Character of Pre-Colonial states in Tropical Africa. Journal of Historical Society of Nigeria, 5(2), 275-289.

Currie, M. (2013). Temporal Perspective: Narrative Futility and the Distribution of Knowledge. Edinburg: Edinburg University Press.

Daron, A., \& James, R. (2012). Why Nations Fail: The origins of Power, Prosperity, and Poverty. New York: Crown Publishing Group.

Daron, A., Simon, J., \& James, R. (2001). The Colonial Origins of Comparative Development: An Empirical Investigation. American Economic Review, 91, 1369-1401.

Dasylva, O. (n.d.). Eritrea: Ideological Battlefield: Deconstructing the Narrative of a Police State. Unpublished Term Paper CONF 695.

Davidson, B. (1995). Africa in History. New York: Simon \& Schuster. 
Douglas, M., \& Marguerite, S. (1978). Context Theory of Classification Learning. Psychological Review, 85(3), 207-238.

Edward, N., Roland, P., \& Oliver, R. (2009). New Perspectives on Liberal Peacebuilding. New York: United Nations University Press.

Faujas, A. (2012, January 12). Africa: Why Francophones are lagging behind Anglophones. Retrieved December 30, 2019, from https://www. theafricareport.com/7810/africa-why-francophones-arelagging-behind- anglophones/

Ferguson, J. (1994). The Anti-Politics Machine. Minneapolis: University of Minnesota Press.

Firchow, P. (2018). Reclaiming Everyday Peace: Local Voices in Measurement and Evaluation after War. Cambridge, U.S.A: Cambridge University Press.

Fortna, V. (2008). Does Peacekeeping Work? Shaping Belligerents' Choices after Civil War. Princeton New Jersey: Princeton University Press.

Frank, A.G. (1969). The Development of Underdevelopment. In T.R. Hite, The Globalization and Development Reader: Perspectives on Development and Global Change (pp. 76-84). Malden MA: Blackwell Publishing.

Harry, M., David, B., Ebenezer, O., John, F.., Shula, M., \& Anthony, L. (2010, December 30). Freedom from Empire: An Assessment of Postcolonial Africa. Retrieved December 30, 2019, from https://www.britannica.com/topic/ Freedom-from-Empire-An-Assessment-of-PostcolonialAfrica-1707631

Heitz, J. (2016). The impact of the Cold War on African security. African Security Review, 25(4), 427430.

Iweriebor, E. (2011). The Colonization of Africa. New York: Schomburg Center for Research in Black Culture.

John, H., \& Daniel, L. (2019). Introduction: Post-conflict Spaces and Approaches to Statebuilding. Journal of Intervention and Statebuilding, 2(3), 269-290.

Kilby, C. (1999). Aid and Sovereignty. Social Theory and Practice, 25(1), 79-92.

Kirdin, S. (2017). A Neo-Realist case study of U.N-Authorized Humanitarian interventions in the PostCold War World. Gazi Universitesi Iktisadi ve Idari Bilimler Fakultesi Dergisi, 19(2), 615-632.

Lange, M., Mahoney, J., \& vom Hau, M. (2006). Colonialism and Development: A Comparative Analysis of Spanish and British. American Journal of Sociology, 111(5), 1412-1462.

Lederach, J. (1997). Building Peace. Washington, D.C: USIP.

Lere, I. (2014). Globalization and Development. The Impact on Africa; A Political Economy Approach. OIDA International Journal of Sustainable Development, 7(9), 153-162.

MacGinty, R., \& Williams, A. (2009). Conflict and Development. New York: Routledge.

Manning, P. (1998). Francophone Sub-Saharan Africa. Cambridge: Cambridge University Press.

Miller, R. (2000). Humanitarian Intervention, Altruism, and the Limits of Casuistry. Journal of Religious Ethics, 28(1), 3-35.

Moore, M. (2015). A Political Theory of Territory. London: Oxford University Press.

Odeh, L. (2010). A Comparative Analysis of Global North and Global South Economies. Journal of Sustainable Development, 12.

Ogbimi, F. (1998). Structural Adjustment is the Wrong Policy. African Technology Forum, 8(1), 23-30.

Oloruntimehin, O. (1982). The Nature of Local Power Under Colonial Rule. Presence Africaine, 3(4), 161-169.

Pitts, J. (2010). Political Theory of Empire and Imperialism. Annual Review of Political Science, 13, 211235.

Reid, S., Andrew, G., Peter, K., Kenju, S., Richard, H., Michael, M., . . . Rene, W. (2017). An Empirical Analysis of Subjectivity and Narrative Levels in Personal Weblog Storytelling Across Cultures. Dialogue and Issues, 8(2), 105-128.

Rimmer, D. (1992). Staying Poor: Ghana's Political Economy, 1950-1990. Oxford: Pergamon Press and the World Bank. 
Rodney, W. (1972). How Europe Underdeveloped Africa. United Kingdom: Bogle-L'Ouverture Publications.

Santos, B. (2019). The Process of Globalization. Revista Critica, 118(103), 1-52.

Schumpeter, J. (1983). Theory of Economic Development. New Jersey: Transaction Publishers.

Sherman, C. (2015, April 15). Nexight Group. Retrieved December 30, 2019, from https://www.nexightgroup.com/new-approaches-to-international- development-part-1/

Simmons, S. (2020). Root Narrative Theory and Conflict Resolution: Power, Justice, and Values. New York: United States: Routledge.

Six, C. (2009). The Rise of Post-Colonial States as Donors: A Challenge to the Development Paradigm. Third World Quarterly, 30(6), 1103-1121.

Stiglitz, J. (2002). Globalization and Its Discontents (p.115). New York: United States: W.W. Norton \& Company.

Stiglitz, J. (2006). Making Globalization Work (p.26). New York: United States: W.W. Norton \& Company.

Talton, B. (n.d.). The Challenge of Decolonization in Africa. Retrieved December 30, 2019, from http://exhibitions.nypl.org/africanaage/essay-challenge-of-decolonization-africa.html

TASD. (n.d.). Age of Imperialism (1870-1914). Retrieved December 9, 2019, from https://www.tamaqua.k12.pa.us/cms/lib07/PA01000119/Centricity/Domain/119/TheAgeofImperi alism.pdf

Thiessen, C., \& Byrne, S. (2018). Proceed with Caution: Research Production and Uptake in ConflictAffected Countries. Journal of Peacebuilding, 13(1), 1-13.

Toshkov, D. (2018, November 6). The 'Global South' is a terrible term. Don't Use it! Research Design Matters.

ushistory.org. (n.d.). The Colonial Experience. Retrieved July 13, 2019.

Uvin, P. (1998). Aiding Violence: Development Enterprise in Rwanda. Connecticut: Kumarian Press.

Woodward, S. (2007). Do the Root Cause of Civil War Matter? On Using Knowledge to Improve Peacebuilding. Journal of Intervention and Statebuilding, 1(2), 143-170.

Zartman, W. (1976, January). Europe and Africa: Decolonization or Dependency. Retrieved December 5, 2019, from https://www.foreignaffairs.com/articles/ africa/1976-01-01/europe-and-africadecolonization-or-dependency

Zeleza, P. (2000). The Causes and Cost of War in Africa. Athens: Ohio University Press. 